\title{
KORELASI RELIGIUSITAS DENGAN KEDISIPLINAN PESERTA DIDIK KELAS XI SEMESTER GENAP TAHUN AJARAN 2015/2016
}

\author{
Sella Rachmawati, * \\ Edi Suresman, Saepul Anwar \\ Program Studi Ilmu Pendidikan Agama Islam, \\ Fakultas Pendidikan Ilmu Pengetahuan Sosial, Universitas Pendidikan Indonesia \\ *Email: sella.rachma26@gmail.com
}

\begin{abstract}
ABSTRAK
Penelitian ini dilatarbelakangi suatu permasalahan yang berkenaan dengan sikap remaja yang kurang berdisiplin baik di lingkungan sekolah maupun lingkungan masyarakat. Sedangkan remaja sedang berada pada masa transisi menuju dewasa. Peran agama tentu berdampak pada pertumbuhan remaja, maka penelitian ini perlu dilakukan, untuk mengetahui sejauh mana hubungan antara religiusitas peserta didik dengan kedisiplinannya. Pendekatan yang digunakan dalam penelitian ini adalah pendekatan kuantitatif dengan metode korelasi. Dari hasil pengolahan data didapat bahwa tingkat religiusitas peserta didik kelas XI di SMA Negeri 13 Bandung dinyatakan berada pada kriteria sedang dengan jumlah rata-rata sebesar 192,2. Sedangkan pada variabel kedisiplinan, didapat bahwa tingkat kedisiplinan peserta didik kelas XI di SMA Negeri 13 Bandung dinyatakan berada pada kriteria sedang dengan jumlah rata-rata sebesar 201,76. Setelah melakukan uji korelasi dan uji regresi, maka dapat disimpulkan bahwa ada hubungan yang kuat antara variabel religiusitas dengan kedisiplinan. Juga ada pengaruh antara religiusitas dengan kedisiplinan sebesar 48,7\%.
\end{abstract}

Kata Kunci: Kedisiplinan, Peserta Didik, Religiusitas, Remaja. 


\section{PENDAHULUAN}

Prilaku disiplin semestinya telah dipupuk sejak dini pada generasi muda bangsa. Hal ini merupakan syarat tak tertulis, karena kelak yang menjalankan roda pemerintahan adalah generasi muda. Namun sangat disayangkan, pada kenyataanya kini bangsa Indonesia masih dihantui oleh beberapa peristiwa yang dianggap lumrah karena beberapa masyarakatnya yang tidak disiplin. Hal ini bisa dilihat dari berita di media bahwa masih banyak pelanggaran lalu lintas oleh penggunanya, para pejabat yang melanggar amanah, korupsi, suap, dan masih banyak lagi pelanggaran kecil maupun besar lainnya.

Sedangkan pada kalangan remaja khususnya pelajar masih banyak yang melakukan pelanggaran seperti bolos sekolah, melanggar tata tertib sekolah, datang terlambat ke sekolah, menyontek, penganiyaan antar teman, bahkan tawuran. Hal ini menggambarkan bahwa ternyata masyarakat Indonesia khususnya usia remaja itu sendiri masih kurang disiplin.

Undang-Undang RI Nomor 20

Tahun 2003 tentang Sistem Pendidikan Nasional mengatakan bahwa pendidikan adalah usaha sadar dan terencana untuk mewujudkan suasana belajar dan proses pembelajaran agar peserta didik secara aktif mengembangkan potensi dirinya untuk memiliki kekuatan spiritual keagamaan, pengendalian diri, kepribadian, kecerdasan akhlak mulia, serta keterampilan yang diperlukan dirinya, masyarakat, bangsa dan negara.

Ditinjau dari tujuan pendidikan, semestinya tidak ada lagi hal-hal yang dilanggar dari manusia yang menerima pendidikan. Karena tujuan pendidikan menurut UU No. 20 tahun 2003 tentang Sistem Pendidikan Nasional pasal 3 adalah untuk berkembangnya potensi peserta didik agar menjadi manusia yang beriman dan bertakwa kepada Tuhan Yang Maha Esa, berakhlak mulia, sehat, berilmu, cakap, kreatif, mandiri, dan menjadi warga negara yang demokratis serta bertanggung jawab.

Demi tercapainya tujuan-tujuan tersebut, maka dalam sekolah dimuat mata pelajaran yang dapat membimbing moral peserta didik. Seperti Pendidikan Kewarganegaraan dan Pendidikan Agama. Setiap jenjang satuan pendidikan memiliki mata pelajaran wajib yaitu Pendidikan Agama.

Bangsa Indonesia adalah bangsa yang mayoritas pendudukanya beragama Islam. Sedangkan Islam mengajarkan umatnya untuk berdisiplin dalam beribadah demi menjadikannya manusia yang religius dan berakhlak mulia. Selain itu, agama Islam juga mengajarkan umatnya untuk berdisiplin dan taat kepada apa yang diperintahkan Allāh dan menjauhi segala yang dilarang-Nya. Prilaku-prilaku tak menghargai waktu, penyelewengan, dan hal yang tidak didiplin lainnya adalah tindakan yang tidak diajarkan dalam Islam bahkan sangat dilarang.

Maka dari itu, seharusnya nilai tingkat rligiusitas berpengaruh kepada nilai tingkat kedisiplinan seseorang.

Menurut Dister (Andisti \& Ritandiyono, 2008, hal. 172) mengatakan bahwa Istilah agama (religion) berasal dari dua kata dalam bahasa latin, yaitu legare dan religio. Legare berarti proses pengi- katan kembali atau penghubungan kembali. Religiusitas adalah sikap batin pribadi (personal) setiap manusia di hadapan Tuhan yang sedikit banyak merupakan misteri bagi orang lain, yang mencakup totalitas kedalam pribadi manusia. Sebagai sikap batin, religiusitas tidak dapat dilihat secara langsung namun bisa tampak dari pengungkapan sikap tersebut.

Teori mengungkapkan bahwa sumber jiwa keagamaan berasal dari faktor intern dan faktor ekstern manusia. Manusia adalah homo religius (makhluk beragama). Potensi tersebut bersumber dari faktor intern manusia yang termuat dalam aspek kejiwaan manusia seperti 
naluri, akal, perasaan, maupun kehendak. Sebaliknya, teori kedua menyatakan bahwa jiwa keagamaan manusia bersumber dari faktor ekstern. Manusia terdorong untuk beragama karena pengaruh faktor luar, seperti rasa takut, rasa ketergantungan, ataupun rasa bersalah (Jalaluddin, 2010, hal. 304).

Sikap relgius seseorang tidak hanya terletak dalam satu dimensi saja tapi juga terletak di banyak dimensi.Glock dan Starck sebagaimana yang dikutip oleh Ancok dan Suroso (2011, hal. 77-78) menyebutkan bahwa ada lima macam dimensi keberagamaan atau religiusitas, di antaranya adalah: 1) dimensi keyakinan, 2) dimensi praktik agama, 3) dimensi pengalaman 4) dimensi pengetahuan, 5) dimensi pengamalan.

Sedangkan pandangan remaja terhadap agama tidak bisa dipastikan dan diberi patokan. Karena setiap pandangan remaja dapat berubah sesuai dengan kejiwaannya. Apabila stabil, maka agama dianggap baik. Sebaliknya, jika kondisi kejiwaannya sedang tidak baik maka agama menurutnya tidak berguna. Namun, semuanya bergantung pada lingkungan di sekelilingnya (Syafaat, Sahrani, \& Muslih, 2008, hal. 181).

Remaja dalam bahasa aslinya disebut adolescence berasal dari bahasa latin adolescere yang artinya tumbuh atau tumbuh untuk mencapai kematangan (Ali \& Asrori, 2009, hal. 9).

Masa remaja adalah masa yang penuh kegoncangan jiwa, masa berada dalam peralihan yang menghubungkan anatara masa kanak-kanak yang penuh dengan keberuntungan ke masa dewasa yang harus berdiri sendiri (Daradjat, Ilmu Jiwa Agama, 2010, hal. 85).

Remaja yang dimaksud adalah remaja yang sedang berada pada lingkungan sekolah, dalam hal ini adalah peserta didik. Ramayulis (2008, hal. 77) mengatakan bahwa peserta didik secara formal adalah orang yang sedang berada pada fase pertumbuhan dan perkembangan baik secara fisik maupun psikis, pertumbuhan dan perkembangan merupakan ciri dari seseorang peserta didik yang perlu bimbingan dari seorang pendidik.

Istilah kedisiplinan menyangkut giatnya usaha dan memenuhi target serta waktu yang tepat (Willis, 2012, hal. 155). Kedisiplinan berasal dari kata disiplin yang mendapat awalan ke dan akhiran -an menurut kamus besar Bahasa Indonesia disiplin mempunyai arti ketaatan dan kepatuhan pada aturan, tata tertib dan lain sebagainya (Badan Pengembangan Kementrian Pendidikan dan Kebudayaan, 2008, hal. 333)

Kedisiplinan siswa sangat dipengaruhi oleh faktor yang ada dari dirinya atau internal dan dari luar dirinya atau eksternal. Faktor internal adalah pemahaman tehadap siapa diri, apa yang diinginkan diri, dan apa yang dilakukan oleh diri sendiri agar hidup menjadi lebih nyaman, menyenangkan, sehat, dan sukses (Yustiana, hal. 3). Sedangkan untuk faktor eksternal di antaranya adalah 1) lingkungan keluarga, 2) lingkungan seklah, dan 3) lingkungan masyarakat.

Unsur-unsur yang ada dalam pembentukan perbuatan atau tingkah laku menurut Drijakara (1962, hal. 9) diantaranya adalah 1) pengethuan, 2) kontrol diri, 3) kesadaran moral, dan 4) kehendak/kebebasan memilih.

\section{METODE}

Dalam penelitian ini, peneliti menggunakan desain deskriptif, dimana peneliti harus memaparkan setiap variabel yang diteliti untuk mendapatkan gambaran hasil yang komprehensif mengenai variabel yang diteliti.

Adapun jumlah responden yang diambil dalam penelitian ini adalah sebanyak 62 responden (sampel) dari populasi sebanyak 292 orang. Adapun teknik sampling yang digunakan dalam menentukan jumlah sampel untuk penelitian ini, peneliti mengacu kepada teknik sampling purposive, yaitu teknik 
penentuan sampel dengan menggunakan pertimbangan tertentu. Sampel yang diambil adalah siswa kelas XI MIA 5 dan XI IIS 2 SMA Negeri 13 Bandung.

Instrumen penelitian menurut Sugiyono (2015, hal. 102) adalah suatu alat yang digunakan untuk mengukur fenomena alam atau soaial yang akan atau sedang diamati. Jadi, instrumen penelitian adalah alat bantu dalam sebuah penelitian untuk mengukur variabel atau hal yang akan diteliti, sehigga dapat menghasilkan kesimpulan dari penelitian tersebut.

Adapun dalam penelitian ini, peneliti akan menggunakan kuisioner dalam bentuk angket. Kuesioner atau angket merupakan teknik pengumpulan data yang dilakukan dengan cara memberi seperangkat pertanyaan atau pernyataan tertulis kepada responden untu dijawabnya (Sugiyono, 2015, hal. 142). Angket yang digunakan dalam penelitian ini adalah angket dalam bentuk pertanyaan tertutup.

Analisis data adalah proses dimana seluruh data telah ada dan siap untuk diolah. Menurut Sugiyono (2015, hal. 147) dalam penelitian kuantitatif, analisis data merupakan kegiatan setelah data dari seluruh responden atau sumber data lain terkumpul. Teknik analisis data dalam penelitian kuantitatif menggunakan statistik. Terdapat dua macam statistik yang digunakan untuk analisis data dalam penelitian, yaitu: statistik deskriptif, dan statistik inferensial.

a. Statistik deskriptif adalah statistik yang digunakan untuk menganalisis data dengan cara mendeskripsikan atau menggambarkan data yang telah terkumpul sebagaimana adanya tanpa bermaksud membuat kesimpulan yang berlaku untuk umum atau generalisasi (Sugiyono, 2015, hal. 147).

b. Statistik inferensial adalah teknik statistik yang digunakan untuk menganalisis data sampel dan hasilnya diberlakukan untuk populasi. Pada statistik inferensial terdapat statistik parametris dan statistik nonparametris. Penggunaan statistik parametris dan nonparametris tergantung pada asumsi dan jenis data yang akan dianalisis (Sugiyono, 2015, hal. 149 - 150).

Tahapan-tahapan yang dilakukan dalam menganalisis data adalah sebagai berikut:

a. Uji prasyarat analisis (uji normalitas). Pada penelitian ini peneliti menggunakan KolmogrovSmirnov untuk menguji normalitas data dengan bantuan software IBM SPSS Statistic 21

b. Uji Korelasi Koefisien korelasi linier sedehana menunjukan dua hal yaitu arah dan besarnya hubungan antara dua variabel. Arah hubungan dinyatakan dengan arah positif atau negatif di depan angka koefisien korelasi. Tanda positif (+) menunjukan hubungan yang searah, sedangkan tanda negatif (-) menujukan hubungan yang berlawanan arah.

Untuk menguji tingkat signifikasi korelasi digunakan rumus:

$$
t_{\text {hitung }}=\frac{r \sqrt{n-2}}{\sqrt{1-r^{2}}}
$$

Sumber: Sugiyono (2015, hal 184)

Keterangan:

$\mathrm{r}=$ koefisien korelasi sederhana

$\mathrm{n}=$ jumlah data atau kasus

Dengan asumsi:

Jika $t_{\text {hitung }}<t_{\text {tabel }}$, maka $H_{o}$ diterima

Jika $t_{\text {hitung }}>\mathrm{t} t_{\text {tabel }}$, maka $H_{o}$ ditolak

Atau

Jika Sig $>\alpha$, maka $H_{o}$ diterima

Jika Sig $<\alpha$, maka $H_{o}$ ditolak

Sumber: (Trihendradi, 2011, hal. 159)

Dalam penelitian ini, peneliti menggunakan software IBM SPSS Statistic 21 untuk mengetahui hasil uji korelasi.
c. Uji Regresi digunakan untuk memprediksi atau menguji 
pengaruh satu variabel bebas (independen) terhadap variabel terikat (dependen).

Adapun rumus persamaan regresi linear sederhana adalah sebagai berikut:

$$
\hat{\mathrm{Y}}=\mathrm{a}+\mathrm{bX}
$$

Sumber: Sugiyono (2015, hal: 188)

Keterangan:

$\hat{Y}=$ Nilai yang diprediksikan

$\mathrm{a}=$ Konstanta atau bila harga $\mathrm{X}=0$

$\mathrm{b}=$ Koefisien regresi

$X=$ Nilai variabel independen

Dalam penelitian ini, peneliti menggunakan software IBM SPSS Statistic 21.

Dari harga koefisien korelasi $r$, bisa menentukan harga koefisien determinasi (KD) yang berguna untuk mengetahui besarnya persentase kontribusi variabel independen terhadap variabel dependen. Rumus yang digunakan sebagai berikut:

$$
\mathrm{KD}=r^{2} \times 100 \%
$$

Sumber: Riduwan (2012, hal. 139)

Keterangan

$\mathrm{KD}=$ Koefisien Determinasi

$r^{2}=$ Kuadrat koefisien determinasi

Dalam penelitian ini, peneliti menggunakan software IBM SPSS Statistic 21 untuk mengetahui koefisien determinasi.

\section{HASIL DAN PEMBAHASAN}

a. Religiusitas

Angket yang dijadikan instrumen yang digunakan dalam pengumpulan informasi tentang religiusitas peserta didik disebarkan di kelas XI IIS 2 dan XI MIA 5 SMA Negeri 13 Bandung yang dilaksanakan pada 17 Mei 2016 dan 19 Mei 2016. Angket tersebut terdiri atas 60 item. Berdasarkan data yang terkumpul dari 62 responden, hasil dari analisis item ditunjukan pada tabel berikut ini

Tabel 1 Tabel Keterangan Presentase Skor Religiusitas Siswa

\begin{tabular}{|l|l|l|}
\hline Interpretasi & Frekuensi & Presentase \\
\hline Tinggi & 5 & $8 \%$ \\
\hline
\end{tabular}

\begin{tabular}{|l|l|l|}
\hline Sedang & 57 & $92 \%$ \\
\hline Rendah & - & 0 \\
\hline
\end{tabular}

Berdasarkan kriteria atau interpretasi pada tabel di atas, maka dapat diketahui bahwa religiusitas pada peserta didik kelas XI MIA 5 dan XI IIS 2 di SMA Negeri 13 Bandung berada dalam kriteria tinggi sebanyak 5 siswa (8\%), berada dalam berada dalam kriteria sedang sebanyak 57 siswa (92\%), berada dalam kriteria rendah sebanyak 0 siswa $(0 \%)$. Dapat disimpulkan bahwa pada uraian di atas menunjukan peserta didik kelas XI MIA 5 dan XI IIS 2 di SMA Negeri 13 Bandung berada pada kriteria sedang, yaitu sebesar $57 \%$, dengan rata-rata sebesar 192,2 dalam kriteria sedang.

Untuk mengetahui interpretasi dimensi dan indikator, maka dapat dilihat dari tabel di bawah ini:

Tabel 2 Interpretasi Dimensi dan Indikator Variabel Religiusitas

\begin{tabular}{|l|c|c|c|}
\hline Dimensi/Indikator & $\begin{array}{l}\text { Rata- } \\
\text { rata }\end{array}$ & $\begin{array}{l}\text { Interpret } \\
\text { asi }\end{array}$ & $\begin{array}{l}\text { Presen } \\
\text { tase }\end{array}$ \\
\hline Keyakinan & $\mathbf{1 9 7 , 2}$ & Sedang & $\mathbf{8 0 \%}$ \\
\hline $\begin{array}{l}\text { Percaya akan adanya } \\
\text { Allāh }\end{array}$ & 198 & Sedang & $80 \%$ \\
\hline $\begin{array}{l}\text { Percaya akan adanya } \\
\text { malaikat Allāh }\end{array}$ & 209,5 & Sedang & $84 \%$ \\
\hline $\begin{array}{l}\text { Percaya akan adanya } \\
\text { kitab-kitab yang } \\
\text { diturunkan Allāh }\end{array}$ & 206,7 & Sedang & $83 \%$ \\
\hline $\begin{array}{l}\text { Percaya akan Rasul } \\
\text { dan Nabi Allāh }\end{array}$ & 206,8 & Sedang & $83 \%$ \\
\hline $\begin{array}{l}\text { Percaya akan adanya } \\
\text { hari akhir }\end{array}$ & 173,3 & Sedang & $70 \%$ \\
\hline $\begin{array}{l}\text { Percaya adanya takdir } \\
\text { Allāh }\end{array}$ & 189 & Sedang & $76 \%$ \\
\hline Praktik Agama & $\mathbf{1 9 3 , 3}$ & Sedang & $\mathbf{7 8 \%}$ \\
\hline Sholat & 167,5 & Sedang & $68 \%$ \\
\hline Puasa & 173,8 & Sedang & $70 \%$ \\
\hline $\begin{array}{l}\text { Berdo'a dan berdzikir } \\
\text { kepada Allāh }\end{array}$ & 198,8 & Sedang & $80 \%$ \\
\hline Zakat & 233 & Tinggi & $94 \%$ \\
\hline Shadaqah & 183,7 & Sedang & $74 \%$ \\
\hline Membaca Al-Qur'an & 203 & Sedang & $82 \%$ \\
\hline Pengalaman & $\mathbf{2 2 0 , 7}$ & Tinggi & $\mathbf{8 9 \%}$ \\
\hline $\begin{array}{l}\text { Bersyukur atas nikmat } \\
\text { Allāh }\end{array}$ & 220,5 & Tinggi & $89 \%$ \\
\hline Tenang saat ibadah & 204,5 & Sedang & $82 \%$ \\
\hline Takut berbuat dosa & 229,5 & Tinggi & $93 \%$ \\
\hline $\begin{array}{l}\text { Hati bergetar } \\
\text { mendengar nama } \\
\text { Allāh }\end{array}$ & 227 & Tinggi & $92 \%$ \\
\hline Ditolong oleh Allāh & 222 & Tinggi & $90 \%$ \\
\hline Pengetahuan Agama & $\mathbf{1 4 0}$ & Rendah & $\mathbf{5 6 \%}$ \\
\hline $\begin{array}{l}\text { Pengetahuan } \\
\text { Keagamaan }\end{array}$ & 140 & Rendah & $56 \%$ \\
\hline Pengamalan & $\mathbf{2 0 7}$ & Sedang & $\mathbf{8 3 \%}$ \\
\hline
\end{tabular}




\begin{tabular}{|l|c|c|c|}
\hline Akhlak kepada Allāh & 223 & Tinggi & $90 \%$ \\
\hline $\begin{array}{l}\text { Akhlak terhadap diri } \\
\text { sendiri }\end{array}$ & 224 & Tinggi & $90 \%$ \\
\hline $\begin{array}{l}\text { Akhlak terhadap } \\
\text { sesama manusia }\end{array}$ & 206 & Sedang & $83 \%$ \\
\hline $\begin{array}{l}\text { Akhlak terhadap } \\
\text { lingkungan }\end{array}$ & 175 & Sedang & $71 \%$ \\
\hline
\end{tabular}

Dilihat dari grafik 4.2 dan diagram pie 4.2 di atas diketahui bahwa dimensi yang paling dominan adalah dimensi pengalaman yaitu dengan rata-rata sekitar 220,7 atau sekitar $89 \%$ dengan interpretasi tinggi. Maksud dimensi pengalaman disini adalah berkaitan dengan pengalaman keagamaan, perasaan-perasaan, persepsipersepsi, dan sensasi-sensasi yang dialami seseorang atau didefinisikan oleh suatu kelompok masyarakat beragama. Misalnya merasa dekat dengan Tuhan, merasa Tuhan telah menolong, merasa takut berbuat dosa, merasa tenang, dan perasaan-perasaan lainnya yang berkaitan dengan keagamaan (Ancok \& Suroso, 2011, hal. 77). Untuk yang paling rendah adalah dimensi pengetahuan agama yaitu dengan jumlah ata-rata sebesar 140 atau dengan jumlah presentase sebesar $56 \%$. Sedangkan untuk dimensi keyakinan, praktik agama, dan pengamalan berada pada interpretasi sedang, atau dengan kata lain masing-masing memiliki rata-rata 197,2, 197,3, dan 207.

b. Kedisiplinan

Angket yang dijadikan instrumen yang digunakan dalam pengumpulan informasi tentang religiusitas peserta didik disebarkan di kelas XI IIS 2 dan XI MIA 5 SMA Negeri 13 Bandung yang dilaksanakan pada 17 Mei 2016 dan 19 Mei 2016. Angket tersebut terdiri atas 60 item. Berdasarkan data yang terkumpul dari 62 responden, hasil dari analisis item ditunjukan pada tabel berikut ini:

Tabel 3 Keterangan Presentase Skor Tingkat Kedisiplinan

\begin{tabular}{|l|l|l|}
\hline Interpretasi & Frekuensi & Presentase \\
\hline Tinggi & 20 & $32 \%$ \\
\hline Sedang & 42 & $68 \%$ \\
\hline Rendah & - & 0 \\
\hline
\end{tabular}

Sumber: Data Penelitian 2016
Berdasarkan kriteria atau interpretasi pada tabel 4.5, maka dapat diketahui bahwa kedisiplinan pada peserta didik kelas XI MIA 5 dan XI IIS 2 di SMA Negeri 13 Bandung berada dalam kriteria tinggi sebanyak 20 siswa (32\%), berada dalam berada dalam kriteria sedang sebanyak 42 siswa (68\%), dan berada dalam kriteria rendah sebanyak 0 siswa (0\%). Dapat disimpulkan bahwa pada uraian di atas menunjukan peserta didik kelas XI MIA 5 dan XI IIS 2 di SMA Negeri 13 Bandung berada pada kriteria sedang, yaitu sebesar $68 \%$.

Untuk mengetahui interpretasi dimensi dan indikator, maka dapat dilihat dari tabel di bawah ini:

Tabel 4. Interpretasi Dimensi dan Indikator Variabel Religiusitas

\begin{tabular}{|c|c|c|c|c|}
\hline $\begin{array}{l}\mathbf{N} \\
\mathbf{o}\end{array}$ & Dimensi/Indikator & $\begin{array}{l}\text { Rata- } \\
\text { rata }\end{array}$ & $\begin{array}{l}\text { Interpr } \\
\text { etasi }\end{array}$ & $\begin{array}{l}\text { Prese } \\
\text { ntase }\end{array}$ \\
\hline $\mathbf{A}$ & Pengetahuan & 212 & Sedang & $85 \%$ \\
\hline 1 & $\begin{array}{l}\text { Mengetahui } \\
\text { perbuatan yang } \\
\text { sesuai dengan } \\
\text { aturan yang ada }\end{array}$ & 213,5 & Sedang & $86 \%$ \\
\hline 2 & $\begin{array}{l}\text { Mengetahui } \\
\text { perbuatan yang } \\
\text { tidak sesuai dengan } \\
\text { aturan }\end{array}$ & 212,6 & Sedang & $86 \%$ \\
\hline 3 & $\begin{array}{l}\text { Mengetahui dampak } \\
\text { dari perbuatan yang } \\
\text { sesuai dengan } \\
\text { aturan }\end{array}$ & 214,5 & Sedang & $86 \%$ \\
\hline 4 & $\begin{array}{l}\text { Mengetahui dampak } \\
\text { dari perbuatan yang } \\
\text { tidak sesuai dengan } \\
\text { aturan }\end{array}$ & 207,5 & Sedang & $84 \%$ \\
\hline $\mathbf{B}$ & Kesadaran Moral & 215,4 & Sedang & $87 \%$ \\
\hline 1 & $\begin{array}{ll}\begin{array}{l}\text { Kesadaran } \\
\text { yang baik }\end{array} & \\
\end{array}$ & 199,1 & Sedang & $80 \%$ \\
\hline 2 & $\begin{array}{l}\text { Kesadaran moral } \\
\text { yang tidak baik }\end{array}$ & 231,7 & Tinggi & $93 \%$ \\
\hline $\mathbf{C}$ & Kontrol Diri & 197 & Sedang & $79 \%$ \\
\hline 1 & $\begin{array}{l}\text { Pengendalian diri } \\
\text { dalam hal positif }\end{array}$ & 186,8 & Sedang & $75 \%$ \\
\hline 2 & $\begin{array}{l}\text { Pengendalian diri } \\
\text { dalam hal negatif }\end{array}$ & 207,1 & Sedang & $84 \%$ \\
\hline D & $\begin{array}{l}\text { Kehendak/kebebas } \\
\text { an Memilih }\end{array}$ & 214 & Sedang & $86 \%$ \\
\hline 1 & Norma agama & 221,7 & Tinggi & $89 \%$ \\
\hline 2 & Norma kesusilaan & 201 & Sedang & $81 \%$ \\
\hline 3 & Norma Kesopanan & 219 & Tinggi & $88 \%$ \\
\hline
\end{tabular}

Dilihat dari pada tabel 4 di atas diketahui bahwa dimensi yang paling dominan adalah dimensi kesadaran moral 
dengan jumlah rata-rata sebesar 215,4 (87\%), dimensi kesadaran moral berbeda tipis dengan dimensi kehendak/kebebasan memilih yakni dengan jumlah rata-rata sekitar 214 (86\%). Kedua dimensi tersebut berada pada kriteria sedang. Dua dimensi lainnya yaitu dimensi pengetahuan memiliki jumlah rata-rata sebesar 212 $(85 \%)$ berada pada kriteria sedang dan dimensi dengan jumlah rata-rata sebsesar 197 (79\%) adalah dimensi kontrol diri dengan kriteria sedang.

c. Pengaruh religiusitas terhadap kedisiplinan peserta didik.

Uji yang dilakukan untuk mengetahui pengaruh religiusitas terhadap disiplin adalah uji korelasi dan uji regresi. Sebelum melakukan beberapa uji untuk mengetahuinya, terlebih dahulu dilakukan uji normalitas.

1) Uji Normalitas. Pengujian normalitas dalam penelitian ini menggunakan teknik One-Sample Kolmogrov-Smirnov. Dengan hasil sebagai berikut:

Menentukan normal atau tidaknya distribusi data berdasarkan acuan jika $\mathrm{p}>$ 0,05 maka distribusi data dinyatakan normal. Sebaliknya, jika $\mathrm{p}<0,05$ maka distribusi dinyatakan tidak normal.pada hasil perhitungan IBM SPSS 21 bisa dilihat bahwa uji normalitas pada variabel religiusitas diperoleh nilai signifikasi Kolmogrov-Smirnov sebesar 0,917 > 0,05. Hasil tersebut menunjukan bahwa distribusi data pada religiusitas adalah normal. Sedangkan uji normalitas pada angket kedisiplinan diperoleh nilai signifikasi $0,610>0,05$. Hasil tersebut menunjukan bahwa sebaran data pada angket kedisiplinan berdistribusi normal.

2) Uji korelasi dilakukan untuk mengetahui hubungan antara variabel $\mathrm{X}$ dan variabel $\mathrm{Y}$, dalam hal ini adalah religiusitas dan kedisiplinan. Berdasarkan hasil analisis, diketahui koefisien korelasi antar variabel independen (X) dengan variabel dependen $(\mathrm{Y})$. dapat dilihat pada data hasil output
IBM SPSS Statistic 21, sebagai berikut

Pada tabel correlations di nilai koefisien korelasi antara religiusitas dengan kedisiplinan adalah 0,698. Maka:

$$
\begin{gathered}
t_{\text {hitung }}=\frac{r \sqrt{n-2}}{\sqrt{1-r^{2}}} \\
t_{\text {hitung }}=\frac{0,698 \sqrt{62-2}}{\sqrt{1-0698^{2}}}=7,54
\end{gathered}
$$

Berdasarkan perhitungan di atas, $t$ hitung sebesar 7,54 dan $t$ tabel ( $t$ tabel di dapat dari perhitungan $M s$. Excel) sebesar 2,000. Maka jika $t_{\text {hitung }}>t_{\text {tabel }}(7,54>$ 2,000) maka $H_{o}$ ditolak. Atau Sig 2 tailed $(0,000)<\alpha(0,01)$ sehingga $H_{o}$ ditolak. Jadi ada hubungan antara variabel religiusitas dengan variabel kedisiplinan. Nilai koefisien korelasi positif, hal ini menunjukan bahwa hubungan yang terjadi adalah hubungan positif. Kenaikan suatu variabel akan menyebabkan kenaikan pada suatu variabel yang lain, sedangkan penurnan suatu variabel akan menyebabkan penurunan suatu variabel lain

3) Uji regresi dilakukan dalam penelitian ini berfungsi untuk mengetahui pengaruh variabel $\mathrm{X}$ terhadap variabel yang dipengaruhinya yaitu variabel $\mathrm{Y}$. Selain itu, uji regresi juga dilakukan untuk memprediksi nilai variabel $X$ yang berpengaruh terhadap variabel Y. Dalam hal ini adalah pengaruh religiusitas terhadap kedisiplinan. Dalam uji regresi ada dua macam uji yang dilakukan, yaitu uji linieritas dan uji koefisien. . Hasil uji linieritas dapat dilihat pada tabel Model Summary dan tabel ANOVA pada output IBM SPSS 21. Berdasarkan tabel Model Summary, kolom R adalah koefisien korelasi yaitu 0,698 yang menunjukan bahwa adanya tingkat hubungan yang kuat antara variabel religiusitas dan variabel kedisiplinan. Sedangkan 
koefisien determinasinya (R Squre) sebesar 0,487. Hasil ini menunjukan bahwa 48,7 \% kedisiplinan pada siswa kelas XI MIA 5 dan XI IIS 2 SMA Negeri 13 Bandung dipengaruhi oleh religiusitas. Sementara sisanya sebesar 51,3\% dipengaruhi oleh faktor lain yang tidak diteliti dalam penelitian ini.

Berdasakan tabel ANOVA, F hitung sebesar 57,049 sedangkan $\mathrm{F}$ tabel sebesar 4,001 atau $\mathrm{F}$ hitung $>\mathrm{F}$ tabel maka $H_{o}$ ditolak. Atau Sig $(0,000)<\alpha(0,05)$ sehingga $H_{o}$ ditolak. Jadi ada hubungan antara variabel religiusitas dengan variabel kedisiplinan. Dengan kata lain, hal ini menunjukan ada pengaruh religiusitas terhadap kedisiplinan pada siswa kelas XI SMA Negeri 13 Bandung dengan mengambil sampel kelas XI MIA 5 dan XI IIS 2.

Untuk mengetahui hasil uji koefisien dapat dilihat pada table coefficients pada output IBM SPSS 21.

Hipotesis yang digunakan untuk koefisien adalah:

$H_{o}=$ Koefisien religiusitas tidak signifikan

$H_{1}=$ Koefisien religiusitas signifikan

Berdasarkan tabel Coefficients di atas $\mathrm{t}$ hitung sebesar 7,553 dan $\mathrm{t}$ tabel sebesar 2,000. Maka Jika $t_{\text {hitung }}>t_{\text {tabel }}$ $(7,553>2,000)$ maka $H_{o}$ ditolakAtau Sig $(0,000)<\alpha(0,05)$ sehingga $H_{o}$ ditolak. Jadi koefisien religiusitas signifikan.

Selain untuk uji koefisien, tabel Coefficients juga digunakan untuk memaparkan uji konstanta. Dengan hipotesis:

$H_{o}=$ Konstanta tidak signifikan $H_{1}=$ Konstanta signifikan

Berdasarkan tabel Coefficients di atas $\mathrm{t}$ hitung sebesar 1,373 dan $\mathrm{t}$ tabel sebesar 2,000. Maka Jika $t_{\text {hitung }}<t_{\text {tabel }}$ $(1,373<2,000)$ maka $H_{o}$ diterima. Atau Sig $(0,175)>\alpha(0,05)$ sehingga $H_{o}$ diterima. Jadi konstanta tidak signifikan. Karena konstanta tidak signifikan, maka model persamaan regresi linier yang terbentuk adalah:

$$
\begin{gathered}
Y=b X \\
=0,885 X
\end{gathered}
$$

Koefisien b dinamakan koefisien arah regresi dan menyatakan perubahan rata-rata variabel $Y$ untuk setiap perubahan variabel X sebesar satu satuan. Perubahan ini merupakan pertambahan bila $b$ bertanda positif dan penurunan bila $b$ bertanda negatif. Persamaan di atas digunakan untuk mengetahui tingkat kedisiplinan siswa ketika tingkat religiusitas diketahui. Jika ingin meningkatkan kedisiplinan siswa maka religiusitas harus ditingkatkan. Misalnya, jika nilai religiusitas siswa sebesar 209 dikalikan 0,885 sama dengan 185. Jadi nilai kenaikan tingkat kedisiplinannya sebesar 185. Atau contoh lainnya adalah, jika nilai tingkat religiusitasnya adalah 1 maka kenaikan tingkat kedisiplinan sebesar 0,885. Koefisien bernilai positif artinya terjadi hubungan yang positif antara tingkat religiusitas dengan kedisiplinan siswa, semakin tinggi tingkat religiusitas. maka semakin bertambah tingkat kedisiplinannya. Begitu pun sebaliknya, semakin turun tingkat religisuitas siswa maka kedisiplnannya pun kan semakin menurun.

Hasil penelitian tersebut sejalan dengan teori yang mendukung penelitian ini bahwa menurut Jalaluddin (2010, hal. 257) sikap keagamaan atau religiusitas merupakan suatu keadaan yang ada dalam diri seseorang yang mendorongnya untuk bertingkah laku sesuai dengan kadar ketaatannya terhadap agama. Sifat keagamaan tersebut oleh adanya konsistensi antara kepercayaan terhadap agama sebagai unsur efektif dan prilaku terhadap agama sebagai unsur konatif.

Sedangkan menurut Ancok dan Suroso (2011, hal. 76) keberagaman atau religiusitas diwujudkan dalam berbagai sisi kehidupan manusia. Aktifitas 
beragama tidak hanya terjadi ketika seseorang melakukan prilaku ritual (beribadah), tetapi juga ketika melakukan aktifitas lain yang didorong oleh kekuatan supranatural.

\section{KESIMPULAN}

Pada variabel religiusitas peserta didik, didapat melalui perhitungan bahwa tingkat religiusitas peserta didik kelas XI SMA Negeri 13 Bandung berada pada kriteria tinggi dan sedang yang didominasi oleh kriteria sedang sebanyak 57 siswa atau sekitar $92 \%$. Sisanya, sebanyak 5 siswa atau $8 \%$ berada pada tingkat religiusitas tinggi, dengan rata-rata pada kriteria sedang. Hal ini dijelaskan lebih terperinci pada perolehan rata-rata dan presentase setiap dimensi dan indikator dalam variabel religiusitas.

Pada variabel kedisiplinan peserta didik kelas XI SMA Negeri 13 Bandung yang telah diteliti melalui perhitungan memperoleh hasil yang berada dalam kriteria tinggi sebanyak 20 siswa (32\%), berada dalam kriteria sedang sebanyak 42 siswa (68\%), dan berada dalam kriteria rendah sebanyak 0 siswa $(0 \%)$. Dapat disimpulkan bahwa pada uraian di atas menunjukan peserta didik kelas XI MIA 5 dan XI IIS 2 di SMA Negeri 13 Bandung berada pada kriteria sedang, yaitu sebesar $68 \%$, dengan rata-rata pada kriteria sedang. Hal ini dijelaskan lebih terperinci pada perolehan rata-rata dan presentase setiap dimensi dan indikator dalam variabel kedisiplinan.

Dalam penelitian ini terungkap bahwa tingkat religisuitas berpengaruh terhadap kedisiplinan. Selain itu, hasil dari korelasi antara religiusitas dengan kedisiplinan menunjukan bahwa hubungannya menunjukan hubungan yang positif. Artinya, jika religiusitas tinggi maka kedisiplinannya pun tinggi. Hubungan yang signifikan tersebut didukung dengan adanya nilai regresi antara variabel religiusitas dan kedisiplinan (R) sebesar 0,698, sedangkan koefisien determinasinya ( $\mathrm{R}$ Squre) sebesar 0,487. Hasil ini menunjukan bahwa 48,7 \% kedisiplinan pada siswa kelas XI MIA 5 dan XI IIS 2 SMA Negeri 13 Bandung dipengaruhi oleh religiusitas, sedangkan sisanya sebanyak 51,3\% dipengaruhi oleh faktor lain.

Melihat sejumlah temuan yang diperoleh dari hasil penelitian mengenai korelasi religiusitas dengan kedisiplinan peserta didik kelas XI semester genap tahun ajaran 2015-2016 di SMA Negeri 13 Bandung, maka penelitian ini dapat diimplikasikan bahwa perlu adanya penanaman nilai-nilai islami bagi para peserta didik demi tercapainya kedisiplinan baik di sekolah, maupun di lingkungan masyarakat.

\section{DAFTAR PUSTAKA}

Ali, M., \& Asrori, M. (2009). Psikologi Remaja. Jakarta: Bumi Aksara.

Ancok, D., \& Suroso, F. N. (2011). Psikologi Islami: Solusi Islam atas Problem-problem Psikologi. Yogyakarta: Pustaka Pelajar.

Andisti, M. A., \& Ritandiyono. (2008). Religiusitas dan Prilaku Seks Bebas pada Dewasa Awal. Psikologi, 1 No. 2, 170-176.

Badan Pengembangan Kementrian Pendidikan dan Kebudayaan. (2008). Kamus Besar Bahasa Indonesia. Jakarta: PT Gramedia.

Daradjat, Z. (2010). Ilmu Jiwa Agama. Jakarta: Bulan Bintang.

Drijarkara. (1962). Percikan Filsafat. Jakarta: PT Pembangunan.

Jalaluddin. (2010). Psikologi Agama. Jakarta: RajaGrafindo Persada.

Ramayulis. (2008). Ilmu Pendidikan Islam. Jakarta: Kalam Mulia.

Riduwan. (2012). Belajar Mudah Penelitian. Bandung: Alfabeta.

Sugiyono. (2015). Metode Penelitian Kuantitatif, Kualitatif, dan R\&D. Bandung: Alfabeta.

Syafaat, A., Sahrani, S., \& Muslih. (2008). Peranan Pendidikan Agama Islam 
dalam Mencegah Kenakalan

Remaja (Juvenile Delinquency).

Jakarta: Rajagrafindo Persada.

Trihendradi, C. (2011). Langka Mudah

Melakukan Analisis Statistik

Menggunakan SPSS 19 Deskriptif

Parametrik Non Parametrik.

Yogyakarta: CV Andi Offset.

Willis, S. (2012). Psikologi Pendidikan.

Bandung: Alfabeta.

Yustiana, Y. R. (n.d.). Pengembangan Disiplin Iswa di Sekolah. PPB FIP UPI, 3. 